\title{
Structure and Efficiency of Crayfish Marketing In Major Markets in Calabar, Cross River State, Nigeria
}

\author{
Ele I. E.* and Nkang, M. O. \\ Department of Agricultural Economics and Extension University of Calabar Calabar, Nigeria
}

\begin{abstract}
This study analyzes the structure and efficiency of marketing of crayfish in Nsidung beach, Watt and IkaIkaOqua markets in Calabar. Primary data were obtained from fifty (50) respondents in the three (3) markets using questionnaires. Data was analyzed using descriptive statistics. The organizational structure is perfectly competitive with some oligopolistic characteristics. The crayfish retail margin averaged 18.98\%, $28.87 \%$, and $32.48 \%$ while the wholesale margin averaged $18.95 \%, 29.82 \%$ and $35.31 \%$ for Nsidung beach, Watt, and IkaIkaOqua markets respectively. Profit analysis in the three (3) markets indicates thatIka-IkaOqua market has a higher profit (A3,500) compared to Nsidung beach (A3,000) and Watt markets (A2,600). Nsidung beach market was $83.72 \%$ efficient, while Watt and IkaIkaOqua markets were $85.77 \%$ and $86.00 \%$ efficient respectively. The study recommends that the marketing efficiency of crayfish product could be increased if restrictions in membership imposed by the crayfish market unions in the three (3) markets are reduced to attract more traders into the crayfish business.
\end{abstract}

Keywords: Crayfish, Marketing efficiency, Market Structure, Marketing Margin, Cost structure.

\section{Introduction: Background Of Study}

Marketing is defined as the performance of business activities that directs the flow of goods and services from producers to the consumers. It can also be defined as the management process responsible for identifying, anticipating and satisfying consumer's requirements profitably. Similarly, agricultural marketing is the performance of all activities that move goods and services from the point of initial agricultural production until they are in hands of the ultimate consumers [1]. It involves all stages of operations which aid the movement of products from the farms to the consumers. The stages include assembling of goods, storages, transportation, processing, grading, packaging and financing of these activities. The common features of marketing are pricing, performance of the different functions of various institutions as well as forces of demand and supply.

Crayfish can be defined as the smoked dried product consisting of a mixture of shrimps, post larvae stages of pink shrimps and other crustaceans, harvested from estuaries and sediments rich coastal waters [2].Crayfish as a source of animal protein holds the promise of reducing protein deficiency in the diet since all food nutrients except carbohydrates are known to be present in crayfish [3]. It is a rich source of lysine, sulphur and amino acids and is therefore suitable for complementing high carbohydrate. It is a good source of thiamine, riboflavin, vitamin $\mathrm{D}$ and $\mathrm{A}$, phosphorus, calcium and iron. It is high in polysaturated fatty acids which are important in lowering blood cholesterol level [2]. Crayfish are highly medicinal because they reduce heart related problems, goiter, etc. especially when consumed in large quantities.

Meals containing crayfish play a great role in the development of humans in the world especially in the lives of people in the developing countries where other protein sources are grossly inadequate and comparatively costly. Experimentally, protein derived from crayfish and fish based diet is as good as that obtained from meat [4]. However, consumption of fish together with products of plants origin which are poor in some amino acids such as Lysine and thiamine, enables not only a complete utilization of plant protein, but also improves the content of the diet. Table 1 shows that $54.37 \%$ of crayfish is made up of protein. Crayfish are found in aquatic habitats and naturally reproduce for food, money, ecological and laboratory purposes. Crayfish fishery in Cross River State has provided business and economic activities for the fishermen of the coastal region where crayfish is found and also crayfish dealers as well as consumers of crayfish [5].Many people in the country today, including fishermen from Cross River State engage in the production and marketing of crayfish owing to its high profitability and as a common means of livelihood.

Table 1:Carcass Composition Of Crayfish

\begin{tabular}{|l|l|}
\hline INGREDIENTS & CONTENT \\
\hline Moisture & $4.6 \%$ \\
\hline Ash & $2.9 \%$ \\
\hline Protein & $54.37 \%$ \\
\hline Energy & $2.14 \mathrm{KJ} / \mathrm{g}$ \\
\hline Lipids & $2.38 \%$ \\
\hline Vitamin B & Rich \\
\hline
\end{tabular}


Source: [6].

The Nsidung beach market is the major landing area as far as crayfish is concerned in Cross River State and its major landing days are Thursday and Sundays. It is legitimately owned by Henshaw Town indigenes, but Nsidung ,Efiat, Oron, and Creek Town people are the primary users with Creek Town dominating in number of fishermen using the beach. Watt market (Calabar Central Market) is the oldest in Cross River State. Major purchases and selling take place here compared to other markets. On the other hand, Ika-IkaOqua market is located in Calabar Municipality and is generally called "Marian Market". Traders in these markets purchases crayfish in large quantities (wholesale) from Nsidung beach for sale to consumer within and outside the Calabar Metropolis. Today, Calabar is one of the seaports in Nigeria known especially in the supply of crayfish, fresh fish, smoked fish, dry fish, periwinkles, crabs, snails and other sea foods.

\title{
Objectives Of The Study
}

The general objective of this research is to economically analyze the structure and efficiency of crayfish marketing in major markets in Calabar, Cross River State, Nigeria

The specific objectives are:

1. To analyze the organizational structure of the three (3) selected markets.

2. To evaluate and compare the crayfish retail marketing margin with the wholesale marketing margin in the three markets.

3. To estimatethe cost structure of crayfish marketing as well as marketing efficiency in the three (3) markets.

\section{Literature Review}

Marketing margin is the difference between the price paid by consumers and that obtained by producers. It can also be defined as the price of a collection of marketing services which is the outcome for the demand for and the supply of such services [1].Marketing margin $=$ Selling price - Supply price $\times 100$

\section{Selling price}

\author{
1
}

[7], in his study about marketing margin existing between wholesale and retail prices showed that as the volume of purchase increases, percentage of retail prices also increases but with constant Naira margins. The study of [2], revealed that marketing margin obtained between wholesale and retail prices has the characteristic nature of increasing, constant or decreasing as quantity of purchases, when expressed in their absolute or percentage margins. Furthermore, marketing margins between terminal markets exhibits some unique characteristics as the volume of quantity purchased.

[8], revealed that, the size of marketing margin depends upon the number of costs of marketing functions. The higher margin is to cover the cost of marketing services and function performed by the marketer. However, many people believe that the large marketing margin reflects "too many middlemen", and that the margin should be reduced by eliminating middlemen. And a small margin denotes greater marketing efficiency which is more desirable than a large margin. If this occurs as in farm roadsides markets where the marketing margin is zero and the farm receives all the consumers' food Naira would represent the most efficient method of marketing [9].

[10], defines market structure as the characteristics of the market organization that is likely to affect the behavior and performance of the firm such as the number of sellers and the size of the firm, the extent of knowledge about each other section and the degree of product differentiation. These characteristics include:

- $\quad$ The number and relative size of buyers and sellers

- $\quad$ Status of knowledge about cost, prices and market conditions among the participants.

- $\quad$ The degree of product differentiation

- $\quad$ The degree of barrier to entry and exit of buyers and seller.

Three theoretical market models often used in analyzing market structure are

- $\quad$ Monopolistic competition

- $\quad$ Perfectly competitive market

- $\quad$ Oligopolistic competition

- $\quad$ Monopoly

Monopolistic competition is a market situation where there are many firms selling differentiated products. Firms are the price makers because of the differentiated product [6]. There is easy entry and exit of firms since the products are differentiated. There are many sellers and buyers.

In a perfectly competitive market, there are many sellers and buyers who produce and sell products which are similar and undifferentiated in the eyes of the buyers. The sellers and buyers have full market knowledge and information that enables them to take decision in the market environment in which they operates. The sellers are price takers and there is no barrier to entry and exits of firms.

In oligopolistic market, there are few sellers and many buyers. Oligopolistic firms are price makers when there are differentiated products. The entry into the market is difficult and in some cases, virtually impossible. 
However, the study conducted by [11], revealed that market structure of crayfish at the retailing and wholesaling levels is more or less an oligopolistic and perfectly competitive one in which there are restriction to entry and many buyers and sellers as such the action of any seller does not influence market price.

Marketing efficiency is the measure of the availability of information that provides maximum opportunities to buyers and sellers to effect transactions with minimum transaction cost. An efficient market is defined as a market where there are large numbers of rational, profit maximizers actively competing, with each trying to predict future market values of individual's securities, and where important current information is almost freely available to all participants [12].

A market is said to be efficient if it rapidly and completely impounds all relevant information on prices. If prices are unfair (that is, the asset is overpriced) then traders will reduce the asset, until reduced demand for purchasing it caused the price to fall. The opposite is the case for underpriced securities [13].

[14], says prices reflects information up to the point where the marginal benefits of acting on the information (the expected profit being made) do not exceed the marginal cost of affecting it. [4], and [15], argued that perfectly informationally efficient markets are impossible if markets are perfectly efficient, the return to gathering information is nil in which case there would be little reason to trade and market will eventually collapse.

[9], carried out a research on analysis of crayfish price - quantity relationship in EsukNsidung in Calabar Metropolis of Cross River State. Data were gotten through the use of questionnaires. He stated that the low margin $(0.5 \%)$ observed by both retail crayfish marketing compared with the wholesale margin $(21.85 \%)$ could be ascribed to the reduced marketing functions performed as well as relatively fewer numbers of middlemen in terms crayfish market.

\section{Methodology}

3.1 Study area: The research work was carried out in three (3) randomly selected major markets of Calabar, Cross River State. They areNsidung beach, Watt and Ika-IkaOqua markets. Calabar fondly referred to as Canaan City by indigenes is situated between latitude $4^{\circ} 55$ and $5^{\circ} 04 \mathrm{~N}$ of the equator and longitude $8^{\circ} 18$ and $8^{\circ} 21 \mathrm{E}$ of the Greenwich meridian [16]. It is about 600 feet above sea level. It has a mean annual rainfall ranging from $3000 \mathrm{~mm}-4000 \mathrm{~mm}$ and annual temperature of between $35^{\circ} \mathrm{C}-37^{\circ} \mathrm{C}$. It lies within the wet humid tropics. The topography is mostly flat and is bordered by two (2) big rivers that is, Cross River State and Atimboriver. The population of Calabar is 371022 comprising of $49.97 \%$ males and $50.03 \%$ females [17]. The climate is tropical and humid. Dry and wet seasons gives rise to rich agricultural activities, and it promotes crayfish multiplication in the rivers.3.2 Sample procedure and sample size:A two-stage sampling procedure was adopted in the study, in other to select the sample.

Stage 1 - Random sampling of three (3) markets out of the six (6) major markets in Calabar. Stage 2 - Random sampling of the crayfish sellers to be used as respondents.

The sampling frame at the wholesale level comprised all the registered members of the different crayfish associations in the selected markets. This was obtained from the presidents of the different crayfish associations. At the retail level, listings were done to create a comprehensive sampling frame for sampling with the crayfish association leaders.Using the simple random technique, wholesalers, and retailers were selected. A total of fifty (50) respondents stratified as 25 wholesalers and 25 retailers were selected. Within each stratum, the respondents were further classified into males and females respectively. With all selected levels, questionnaires were used to obtain information in terms of buying and selling strategies, financing, profit, entry and exit barriers and trade relationships.

3.3 Data collection: The data used for the study was obtained from both primary and secondary sources. Primary data was gotten through personal interviews, direct observations and validated structured questionnaires whose content comprised open ended questions. Secondary sources such as annual reports, journals, internet, textbooks, and encyclopedia, were used to gather information. The wholesale prices at Nsidung beach market were obtained from the selected crayfish dealers who habitually travel to Efiat, Bakassi and Oron (major crayfish landing areas) by engine boats to buy crayfish in bags and on return sell to wholesalers on Thursdays and Sundays(landing days when prices of crayfish low).Secondly, questionnaires was distributed to fifty (50) respondents, to enable them record their weekly sales/purchases quantities and price as well as other information on marketing. This record keeping was done for twelve (12) weeks. The obtained information was used to assess market performance on the three (3) markets. Hence, the price and quantities information and data collected include:

- $\quad$ The price at which the crayfish traders in the study area buy

- $\quad$ The selling price for all wholesalers.

- $\quad$ The selling price for all selected retailers

- $\quad$ Quantities purchased and sold by wholesalers and retailers. 
Data analysis: Objective 1 was analyzed descriptively using tables, frequencies, and percentage distribution. Parameters estimated were mean, standard deviations, coefficient of variability. The formulas adopted are as follows

Mean $X=\sum_{N}$

Where,

$\mathrm{N}=$ Number of observations

$\sum \mathrm{X}=$ Summation of the observations

Standard deviation $(\delta)=\underline{\sqrt{\sum}(\mathrm{X}-\mathrm{X})^{2}}$

$\delta=$ Standard deviation N-1Where,

$\mathrm{X}=$ Observations

$\mathrm{X}=$ Mean of $\mathrm{X}$

$\mathrm{N}=$ Number of observation.

Coefficient of Variability $(\mathrm{CV})=\frac{\delta}{\mathrm{X}} \times \frac{100}{1}$

Where $\delta$ and $\mathrm{X}$ are as already defined

Objective 2 and 3 were analyzed using budgetary analysis and shepherds futrel method. Parameters estimated were net income, gross margin, profit and marketing efficiency.

The Net income from crayfish marketing is stated as: NI = GM - FC

Where,

$\mathrm{NI}=\mathrm{Net}$ income from crayfish marketing activities

$\mathrm{GM}=$ Gross margin

$\mathrm{FC}=$ Fixed Cost

Gross margin $(\mathrm{GM})=\mathrm{TR}-\mathrm{TVC}$

Profit $=$ TR - TC

Where,

$\mathrm{TR}=$ Total revenue

TVC $=$ Total variable cost

$\mathrm{TC}=$ Total cost

Marketing efficiency $=\frac{\text { Marketing output }}{\text { Marketing input }} \times \frac{100}{1}$

Marketing efficiency using shepherds futrel method $=\underline{\text { Revenue }} \times \underline{100}$

$\approx$ Value of goods sold $\times \underline{100}$

Total marketing cost 1

Retail margin $(\mathrm{N})=$ Retail price/bag - wholesale price /bag

Retail margin $(\%)=$ Retail price/bag - wholesale price $/$ bag $\quad \times \quad \underline{100}$

Wholesale price per bag

Wholesale margin $(\mathrm{N})$ for Watt/Ika-IkaOqua market

$=$ Wholesale price at Watt/Ika-IkaOqua -wholesale price at Nsidung beach

Wholesale margin (\%) for Watt/Ika-IkaOqua market

$=$ Wholesale price at Watt/Ika-IkaOqua - Wholesale price at Nsidung beach

wholesale price at Nsidung beach

\section{Results And Discussion}

\subsection{ORGANIZATION AND STRUCTURE IN THE THREE (3) MARKETS}

4.1.1 Nsidung beach market:Crayfish market structure here consists of considerable number of retailers and wholesalers. There exists both retailers wholesalers unions operating at the market. Their existence not only created conducive atmosphere in the transaction of the product, but also minimized problems at both retailing and wholesaling stages of crayfish marketing. A prospective retailer has to register formally with the union with the following requirements:

(a) N500.00 registration fee (b) Five (5) crates of soft drinks

Similarly, this is also applicable in the wholesalers union, where an intending member becomes a bonafide member on settlement of the following;

(a) N500.00 registration fee

(b) Five (5) crates of soft drinks+ 3 cartoons of star and small stout each. 
(c) Two bottles of hot drinks

(d) Member willingness to contribute to any member in time of need

(e) Regular attendance of meeting and payments of dues during each meeting

(f) Acquisition of permanent shade at rate of N500.00 monthly.

In Nsidung beach market, the market structure could be seen as perfectly competitive markets with some oligopolistic characteristics, since there is always restriction to entry into the market imposed by the members of the union, as only financial members of the association are allowed to enter and trade freely on the commodity without obstruction. There are many sellers and buyers such that the action of one buyer or seller has no significant effect on the market price of goods sold.

4.1.2 Ika-IkaOqua market: Members of this crayfish market are dominated by women. Membership of the union is between 250 and 300. Like the Nsidung beach market, the condition for entry into the market is not free, as members must register in the union and must have fulfilled the following requirements:

(a) Registration fee of $\mathrm{N} 2000.00+3$ cartoons of beers

(b) Three (3) cartoons of small stout +3 crates of malt

(c) Five (5) crates of mineral +2 bottles of hot drink

(d) Five packets of biscuit and specific quantities of groundnut

Members also pay N1000.00 each to be used in running the union and extra charge is usually added and levied on all members if there was to be any ceremony, like marriage, child dedication, funeral, etc.

Hence, the structure of Ika-IkaOqua crayfish market is perfectly competitive, since there are many small sellers and buyers, such that no one seller has a perceived influence on market price of crayfish sold.

4.1.3 Watt market: Here, the market union consists of 280 members (registered), majority of which are women. Permanent membership remains unchanged since the establishment of the unionbecause new members are not allowed into the union except they form partners with registered members. The activities of this market union restricts entry into the market, hence, the few sellers. Market structure is perfectly competitive with some traits of oligopolistic characteristics. These findings are in line with [18], and [19]. There are many buyers and sellers, such that no one seller has perceived influence on the market price of crayfish sold.

\subsection{COMPARISON OF CRAYFISH RETAIL MARGIN WITH THE WHOLESALE MARKETING MARGIN IN THE THREE (3) MARKETS OF CALABAR.}

Table 2 below, summarizes the estimated marketing margins and percentage margins at both wholesale and retail prices of crayfish on monthly basis.The highest and lowest retail marketing margins was $20.00 \%$ and $18.18 \%$ for Nsidung beach market, $30.56 \%$ and $26.32 \%$ for Watt and $36.11 \%$ and $29.74 \%$ for Ika-IkaOqua markets respectively. The highest and lowest wholesale marketing margins was $20.00 \%$ and $18.18 \%$ for Nsidung beach, $33.33 \%$ and $27.18 \%$ for Watt and $38.89 \%$ and $32.31 \%$ for Ika-IkaOqua markets respectively while the mean wholesale margin was $18.98 \%, 29.82 \%$ and $35.31 \%$ respectively. The Nsidung beach had the same percentage margin for both retail and wholesale while the decreased retail margin in Watt and IkaIkaOqua market portrays decreased marketing function of the crayfish product at the retailer's level. The price of crayfish sold in Nsidung beach market was low compared to Watt and Ika-IkaOqua markets, irrespective of the season.

TABLE 2: ESTIMATED WHOLESALE AND RETAIL MARKETING MARGINS AND AVERAGE

\begin{tabular}{|c|c|c|c|c|c|c|c|c|c|c|}
\hline Months & $\begin{array}{l}\text { Fisherme } \\
\text { n from } \\
\text { Ineh } \\
\text { wholesale } \\
\text { price/bag } \\
\text { (N) }\end{array}$ & $\begin{array}{l}\text { Nsidung } \\
\text { beach } \\
\text { retail/whole } \\
\text { sale } \\
\text { price/bag } \\
\text { (N) }\end{array}$ & $\begin{array}{l}\text { Watt } \\
\text { Av. } \\
\text { Retail } \\
\text { price/b } \\
\text { ag }(\mathbf{N})\end{array}$ & $\begin{array}{l}\text { IkaIkaO } \\
\text { qua } \\
\text { retail } \\
\text { price/ba } \\
\text { g }(\mathbf{N})\end{array}$ & $\begin{array}{l}\text { Nsidun } \\
\text { g retail } \\
\text { margin } \\
(\mathrm{N})\end{array}$ & $\begin{array}{l}\text { Watt } \\
\text { retail } \\
\text { margi } \\
n(N)\end{array}$ & $\begin{array}{l}\text { IkaIka } \\
\text { Oqua } \\
\text { retail } \\
\text { margi } \\
\text { n }(\mathbf{N})\end{array}$ & $\begin{array}{l}\text { Nsidun } \\
\text { g retail } \\
\text { margin } \\
(\%)\end{array}$ & $\begin{array}{l}\text { Watt } \\
\text { retail } \\
\text { margi } \\
\text { n }(\%)\end{array}$ & $\begin{array}{l}\text { IkaIka } \\
\text { Oqua } \\
\text { retail } \\
\text { margin } \\
(\%)\end{array}$ \\
\hline $\begin{array}{l}\text { Sept. } \\
2013 \\
\text { Oct. } 2013 \\
\text { Nov. } 2013 \\
\end{array}$ & $\begin{array}{l}15000 \\
16000 \\
16500\end{array}$ & $\begin{array}{l}18000 \\
19000 \\
19500\end{array}$ & $\begin{array}{l}23500 \\
24000 \\
24300\end{array}$ & $\begin{array}{l}24500 \\
25000 \\
25300\end{array}$ & $\begin{array}{l}3000 \\
3000 \\
3000\end{array}$ & $\begin{array}{l}5500 \\
5000 \\
4800\end{array}$ & $\begin{array}{l}6500 \\
6000 \\
5800\end{array}$ & $\begin{array}{l}20.00 \\
18.75 \\
18.18\end{array}$ & $\begin{array}{l}30.56 \\
26.32 \\
29.74\end{array}$ & $\begin{array}{l}36.11 \\
31.58 \\
29.74\end{array}$ \\
\hline $\begin{array}{l}\text { Total } \\
\text { Mean } \\
\text { SD } \\
\text { CV (\%) } \\
\text { Variance }\end{array}$ & $\begin{array}{l}47500 \\
15833.33 \\
763.76 \\
4.82 \\
583333.33\end{array}$ & $\begin{array}{l}56500 \\
18833.33 \\
763.76 \\
4.06 \\
583333.33\end{array}$ & $\begin{array}{l}71800 \\
23933.3 \\
3 \\
404.15 \\
1.69 \\
163333 . \\
33 \\
\end{array}$ & $\begin{array}{l}74800 \\
24933.3 \\
3 \\
404.15 \\
1.62 \\
163333 . \\
33 \\
\end{array}$ & $\begin{array}{c}9000 \\
3000 \\
- \\
- \\
-\end{array}$ & $\begin{array}{l}15300 \\
5100 \\
360.56 \\
7.07 \\
130000\end{array}$ & $\begin{array}{l}18300 \\
6100 \\
360.56 \\
5.91 \\
130000\end{array}$ & $\begin{array}{l}59.93 \\
18.98 \\
0.9309 \\
4.90 \\
0.8667\end{array}$ & $\begin{array}{l}86.62 \\
28.87 \\
2.248 \\
9 \\
7.79 \\
5.057 \\
8 \\
\end{array}$ & $\begin{array}{l}94.43 \\
32.48 \\
3.2783 \\
10.09 \\
0.7473\end{array}$ \\
\hline
\end{tabular}




\section{Percentage Margins}

\begin{tabular}{|c|c|c|c|c|c|c|c|c|c|c|}
\hline Months & $\begin{array}{l}\text { Fisherme } \\
\text { n from } \\
\text { Ineh } \\
\text { wholesal } \\
\text { e } \\
\text { price/bag } \\
\text { (N) }\end{array}$ & $\begin{array}{l}\text { Nsidung } \\
\text { beach } \\
\text { wholesal } \\
\text { e } \\
\text { price/bag } \\
\text { (N) }\end{array}$ & $\begin{array}{l}\text { Watt } \\
\text { wholesal } \\
\text { e } \\
\text { price/bag } \\
\text { (N) }\end{array}$ & $\begin{array}{l}\text { IkaIkaO } \\
\text { qua } \\
\text { wholesal } \\
\text { e } \\
\text { price/bag } \\
\text { (N) }\end{array}$ & $\begin{array}{l}\text { Nsidun } \\
\text { g } \\
\text { wholes } \\
\text { ale } \\
\text { margin } \\
\text { (N) }\end{array}$ & $\begin{array}{l}\text { Watt } \\
\text { wholes } \\
\text { ale } \\
\text { margi } \\
\text { n }(\mathbf{N})\end{array}$ & $\begin{array}{l}\text { IkaIka } \\
\text { Oqua } \\
\text { wholes } \\
\text { ale } \\
\text { margin } \\
\text { (N) }\end{array}$ & $\begin{array}{l}\text { Nsidu } \\
\text { ng } \\
\text { wholes } \\
\text { ale } \\
\text { margi } \\
\text { n }(\%)\end{array}$ & $\begin{array}{l}\text { Watt } \\
\text { wholes } \\
\text { ale } \\
\text { margin } \\
(\%)\end{array}$ & $\begin{array}{l}\text { IkaIka } \\
\text { Oquaw } \\
\text { holesal } \\
\text { emargi } \\
\text { n }(\%)\end{array}$ \\
\hline $\begin{array}{l}\text { Sept. } \\
2013 \\
\text { Oct. } 2013 \\
\text { Nov. } 2013 \\
\end{array}$ & $\begin{array}{l}15000 \\
16000 \\
16500\end{array}$ & $\begin{array}{l}18000 \\
19000 \\
19500\end{array}$ & $\begin{array}{l}24000 \\
24500 \\
24800\end{array}$ & $\begin{array}{l}25000 \\
25500 \\
25800\end{array}$ & $\begin{array}{l}3000 \\
3000 \\
3000\end{array}$ & $\begin{array}{l}6000 \\
5500 \\
5300\end{array}$ & $\begin{array}{l}7000 \\
6500 \\
6300\end{array}$ & $\begin{array}{l}20.00 \\
18.75 \\
18.18\end{array}$ & $\begin{array}{l}33.33 \\
28.95 \\
27.18\end{array}$ & $\begin{array}{l}38.89 \\
34.21 \\
32.31\end{array}$ \\
\hline $\begin{array}{l}\text { Total } \\
\text { Mean } \\
\text { SD } \\
\text { CV (\%) } \\
\text { Variance }\end{array}$ & $\begin{array}{l}47500 \\
15833.33 \\
763.76 \\
4.82 \\
583333.3 \\
3\end{array}$ & $\begin{array}{l}56500 \\
18833.33 \\
763.76 \\
4.06 \\
583333.3 \\
3\end{array}$ & $\begin{array}{l}73300 \\
24433.33 \\
404.15 \\
1.6541 \\
163333.3 \\
3\end{array}$ & $\begin{array}{l}76300 \\
25433.33 \\
404.15 \\
1.5890 \\
163333.3 \\
3\end{array}$ & $\begin{array}{c}9000 \\
3000 \\
- \\
- \\
-\end{array}$ & $\begin{array}{l}16800 \\
5600 \\
360.56 \\
6.4385 \\
130000\end{array}$ & $\begin{array}{l}19800 \\
6600 \\
360.56 \\
5.4629 \\
130000\end{array}$ & $\begin{array}{l}59.93 \\
18.98 \\
0.9309 \\
4.90 \\
0.8667\end{array}$ & $\begin{array}{l}89.46 \\
29.82 \\
3.1659 \\
10.62 \\
10.0233\end{array}$ & $\begin{array}{l}105.4 \\
35.31 \\
3.3931 \\
9.61 \\
11.513 \\
2\end{array}$ \\
\hline
\end{tabular}

Field survey data, 2013

TABLE 3: COST STRUCTURE OF CRAYFISH MARKETING IN THE THREE (3) MAJOR

\section{MARKETS OF CALABAR}

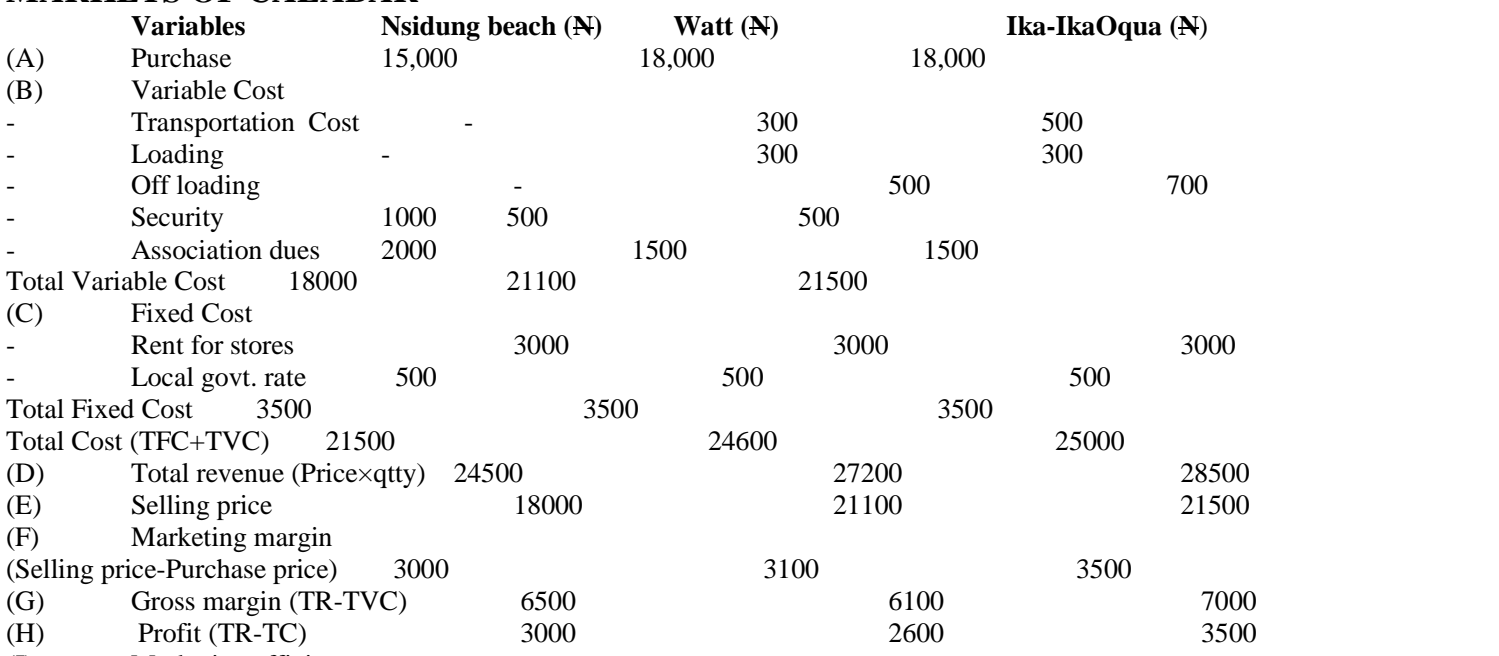

(I) Marketing efficiency

(Sepherdfutrel method) $\quad 83.72 \%$

Source: Field survey data, 2013

Table 3 above, shows the cost structure of crayfish marketing in Calabar. The estimate shows that the total marketing cost in Nsidung beach market is low compared to Watt and Ika-IkaOqua market due to the fact that crayfish traders in Nsidung beach market are not subjected to some charges like loading/off loading and transport cost compared to Watt and Ika-IkaOqua. Similarly, profit and marketing efficiency(86.00\%) is higher in Ika-IkaOqua market due to high price charge per bag of crayfish and the increased marketing cost, since it is located in the municipality area dominated by rich people who can afford to purchase the product at increased rate, in addition to increased transportation/labor charges compared to Watt (85.77\%) and Nsidung beach market $(83.72 \%)$, located in Calabar South dominated by low income earners.

\section{Recommendations}

- The marketing efficiency of crayfish product could be enhanced if restrictions on membership imposed by the crayfish unions in the three (3) markets are removed to attract more traders into this crayfish business.

- The profits of the retailer in Watt market which is significantly lower thanthat obtained by the wholesalers in Nsidung beach market could be improved by advising the retailers to buy more bags of crayfish and sell them.

- A conducive atmosphere should be created to enhance marketing efficiency, and central storage facilities should be provided to enhance storage and preservation of the product.

- Subject matter specialist in marketing and preservation of this product should be sent to educate the members of the association on how reserve and store the product for long shelf life. 
- Marketing efficiency is affected by poor market structure (instability), poor road network, high cost of transportation, and lack of market information these can be increased by tailoring policy towards measures that will reduce marketing cost.

- Further research should be carried out to ascertain the crayfish marketing margin at the wholesale and retail level in the area, and overtime were possible.

\section{References}

[1]. Olukosi, J. O. [1990]:Introduction to Agricultural Marketing and Prices: Principles and Applications, ObafemiAwolowo University Press Limited, lle-ife.

[2]. Asibong, A. E. [1992]: Analysis of Crayfish Quantity and Price Relationship and Marketing Margin InEsukNsidung of Calabar South, Cross River State. A Bachelor of Agriculture Degree Dissertation to the Faculty of Agriculture, University of Calabar.

[3]. Udoh, N. A. [1997]: Analysis of Crayfish in Calabar South Local Government Area of Cross River State. A Bachelor of Agriculture Degree Dissertation to the Faculty of Agriculture, University of Calabar.

[4]. Ebe, S. A [2007]: Fuel Wood Marketing Nigeria,London Macmillan Publishers, London.

[5]. Agwumba, C. E.[2009]:Fresh Maize Marketing in Nigeria, Oxford University Press, New York.

[6]. Paxton, M. (1995): Agriculture of Fresh Water Crayfish - Cherax Destruction, Bellows Kenton Limited, Alabama U.S.A, Pp 12-30.

[7]. Douglas, U. E. [1986]: Economics of Fish Production in Calabar South Local Government Area of Cross River State, A Bachelor of Agriculture Degree Dissertation to the Faculty of Agriculture, University of Calabar.

[8]. Kohl, R. L. and Uhl, J. N. [1985]: Marketing of Agricultural Products, Macmillan Publishing Company, New York.

[9]. John, J. [1994]: Analysis of Crayfish Price Relationship in Calabar, A Bachelor of Agriculture Degree Dissertation to the Faculty of Agriculture.

[10]. Idiong, C. I. [1992]: A Study of Fish Margin InEsukNsidung of Calabar. A Bachelor of Agriculture Dissertation to the Faculty of Agriculture, University of Calabar.

[11]. Danby, B. A. [1986]: Retail Price Dispersion, ObafemiAwolowo University Press Limited, llelfe.

[12]. Varian, H. R. [1980]: “A model of Sales”: The American Economic Review, Vol. 70.

[13]. Onah, J. O. [1979]: Marketing in Nigeria - Experience in a Developing Economy, Cassel Limited, London.

[14]. Abbott, J. C and Makeham, J. P. [1979]: Agricultural Economics and Marketing in the Tropics, Longman Group Limited, London.

[15]. Asukpa, A. U. [1999]: Fresh Fish Marketing Margin, A Case of Mkpanak Fish Market in Ibiono Local Government Area. A Bachelor of Agriculture Degree Dissertation to the Faculty of Agriculture, University of Calabar.

[16]. Ukoha, O.O [1998]: The Fishing Subsector in Nigeria and Analysis of Output Performance the way forward in Agricultural Development, AbubakarTafewaBalewa University Press, Zaria, pp.22-28.

[17]. National Population Commission [NPC, 2006],Retrieved from: http://www.population.gov.ng/state/cross riverfinal.pdf

[18]. Eboh, C. N. [1990]:Interstate Marketing of Palm Oil:A Case Study of Palm Oil Marketing in Imo State, B.Sc Dissertation Submitted to the Faculty of Agriculture, University of Calabar.

[19]. Nsentip, N. U. [1986]: A Review of Crayfish Fishery of Nigeria with Special Reference to the Cross River State Fisher Division, Calabar, Pp 42-46. 